\title{
FLOW TILLS AND RELATED DEPOSITS ON SOME VESTSPITSBERGEN GLACIERS
}

\author{
By G. S. Boulton \\ (Department of Geology, University of Birmingham, Birmingham, England)
}

\begin{abstract}
Anstract. Three outlet glaciers of the highland ice of Ny Friesland are described, in which englacial debris, derived from the glacier bed, occurs in thick bands which dip steeply up-glacier. As the glacier wastes down this debris is released on the surface to form thick supraglacial tills, which may remain on the glacier surface. or flow down it and onto bedded deposits which fringe the glacier in the proglacial zone. A frequent result of this latter process is the production of multi-till sequences which result from a single glacier retreat phase rather than multiple advance and retreat. The sedimentological features and fabrics of englacial debris bands and flow tills are described, and a mechanism for the formation of "controlled" and "uncontrolled" hummocky moraine is suggested. Many flow tills are identical to the compact fine-grained tills common in lowland glacial deposits of Pleistocene age in Europe and North America, and it is suggested that some of the latter could be flow tills.
\end{abstract}

RÉsumÉ. Dépóts glaciaires consolidés d'écoulement et dépôts apparentés sur quel ques glaciers du Vestspitsbergen. Trois glaciers d'écoulement de la calotte glaciaire de Ny Friesland sont décrits, dans lesquels des débris intraglaciaires provenant du lit sont disposés en bandes épaisses plongeant abruptement vers l'amont. Comme le glacier s'abaisse, ces débris apparaissent à la surface pour y former d'épais dépóts supraglaciaires. qui peuvent ou bien y rester ou alors s'écouler sur des dépôts marginaux de la zone proglaciaire. Le résultat fréquent de ce dernier processus est une séquence de nervures qui résultent plutôt d'un seul retrait du glacier que d'avances et retraits multiples. On décrit les traits et la structure sédimentologiques des bandes de débris intraglaciaires et des nervures; on suggère un mécanisme de formation de moraine à mammelons "contrólée" et "non contrôléc". De nombreux dépôts ont l'aspect compact et le grain fin communs aux dépôts glaciaires du pléistocène des plaines de l'Europe et de l'Amérique du Nord. On suggère que certains de ceux-ci pourraient ĉtre des dépôts glaciaires consolidés.

Zusammenfassung. Fliessgeschiebe und verwandte Ablagerungen auf einigen Gletschern in Vestspitsbergen. Drei aus dem Hochlandeis von Ny Friesland abfliessende Gletscher werden beschrieben, deren aus dem Gletscherbett aufgenommene Innenmoräne in dicken, steil gletscheraufwärts einfallenden Bändern auftritt. Mit dem Abtauen des Gletschers wird dieser Schutt auf der Oberfläche frei und bildet dort mächtige Geschicbe. die auf der Gletscheroberfläche bleiben oder von ihr auf geschichtcte Ablagerungen im Gletschervorfeld abfliessen. Ein häufiges Ergebnis des letzteren Vorgangs ist die Entstchung eines vielschichtigen Geschiebemergels, der eher von einer einzigen Rückgangsphase herstammt als von mehrfachen Vorstössen und Rückzügen des Gletschers. Die sedimentologischen Erscheinungen und Strukturen der Bänder aus Innenmoräne und der Fliessgeschiebe werden beschricben und der Vorgang der Bildung "kontrollierter" und "unkontrollierter" buckliger Moränen wird hergeleitet. Viele Fliessgeschiebe sind identisch mit den kompakten, feinkörnigen Geschieben, wie sie in pleistozänen Glazialablagerungen des europäischen und nordamerikanischen Tieflandes häufig vorkommen, und es wird die Vermutung ausgesprochen. dass einige der letzteren ebenfalls Fliessgeschiebe sind.

\section{INTRODUCTION}

In the glaciers of northern Vestspitsbergen and Nordaustlandet, debris derived from the glacier bed is carried englacially as a series of bands. These bands are up to $5 \mathrm{~m}$ thick and often have a debris content as great as 80 per cent by volume. Some of the larger glaciers, such as the distributory glaciers of the highland ice of Ny Friesland and the ice-cap margin in Nordaustlandet (Donner and West, I957), contain enormous volumes of debris; it is estimated that the snout of one large glacier (Dunerbreen) contains sufficient debris to produce a till at least $8 \mathrm{~m}$ thick on melting of the containing ice. In those glaciers which are in a state of longitudinal tension this debris load is generally carried englacially just above the glacier bed, but if the snout is in a state of compression, the resultant upward component of glacier movement transports this load towards the surface. In this latter case, lowering of the glacier surface by ablation causes debris bands to crop out on it as a series of low ridges, which tend to collapse as the interstitial ice melts, giving rise to highly fluid tills which flow down the glacier surface. These "flow tills" often cover wide areas of the glacier snout, and they may build up to considerable thicknesses in hollows and flat areas (the maximum observed thickness is $5 \mathrm{~m}$ ), whilst in places they flow off the glacier surface and over the sediments in the adjacent proglacial zone. 
The descriptions and discussions which follow illustrate the mode of occurrence of englacial debris, the way in which supraglacial flow tills form, their sedimentological characters and fabrics, and their spacial and contact relationships with other sediments. The three glaciers which are used as examples, Dunerbreen, Valhallfonna and Stubendorfbreen, are all outlets of the highland ice of Ny Friesland, their locations being marked in Figure I. The highland ice of

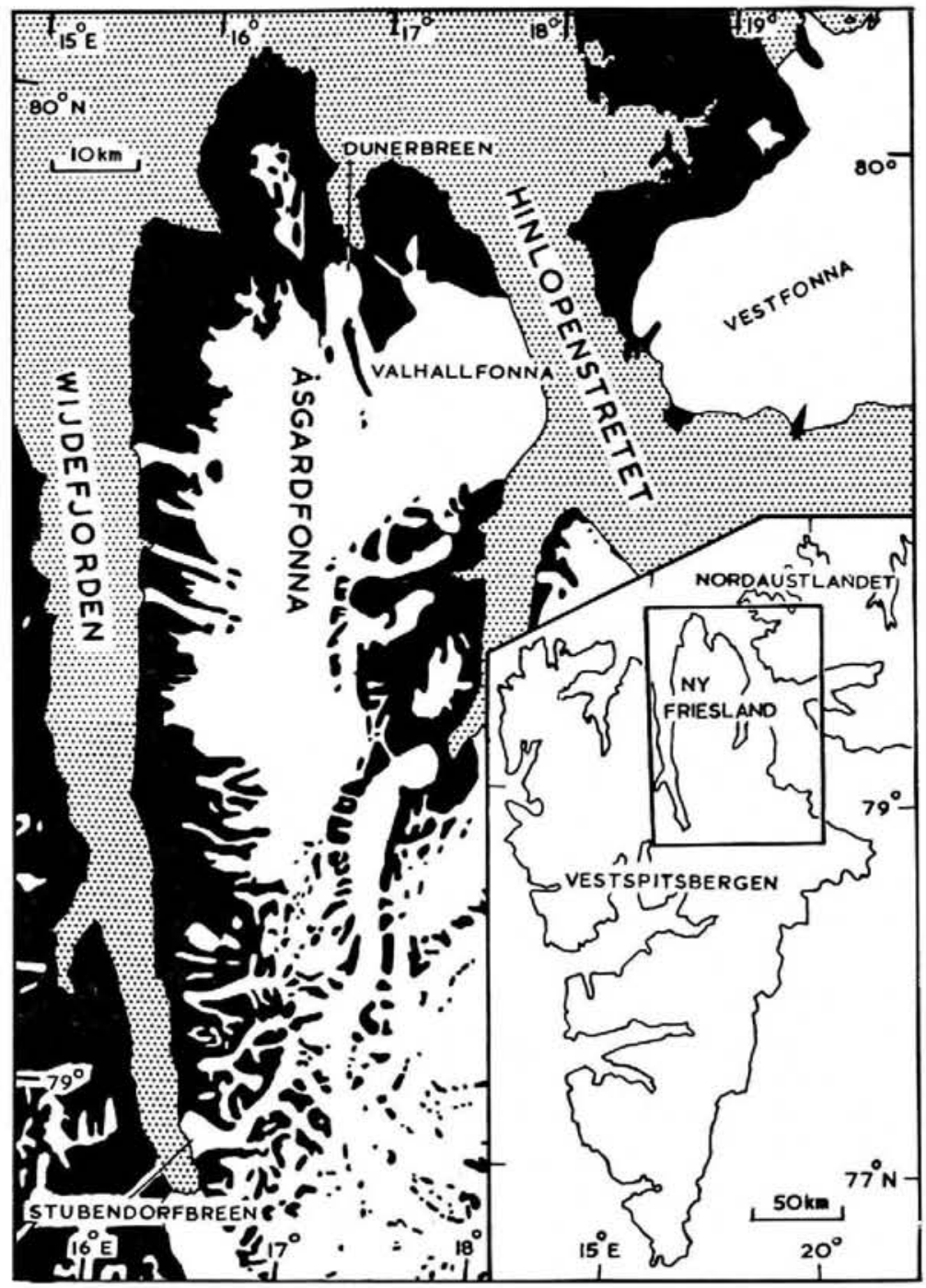

Fig. I. Map of Ny Friesland showing the three glaciers described in the text: Dunerbreen, Valhallfonna and Stubendorfbreen. The map is located on the inset showing Vestspitsbergen and part of Nordaustlandet.

Ny Friesland is a dome of ice which covers an irregular mountainous topography, but which is broken up in its southern part by a large number of nunataks. Dunerbreen and Stubendorfbreen are outlet glaciers of this dome and they occupy valleys cut through the hills which border it in the north and west, respectively. Valhallfonna, merely a westerly extension of this dome, flows into the sea. All three glaciers terminate on a broad coastal flat, producing end moraines and extensive flow tills, the features of which are described in this paper. 


\section{DUNERBREEN}

Dunerbreen is the most northerly distributary glacier of Asgardfonna (the northern lobe of the highland ice of $\mathrm{Ny}$ Friesland); it is a low-angle glacier tongue (the gradient of the terminal $3 \mathrm{~km}$ is $1-2^{\circ}$ ), which flows over Hecla Hoek schists and which is terminated by a bi-lobed moraine at the head of Sorgfjorden (Fig. 2). The terminal moraine of the glacier, which is up to I $\mathrm{km}$ broad, is ice-cored and has a hummocky surface form; the observations presented here will deal only with part of the western lobe of this moraine. This western lobe

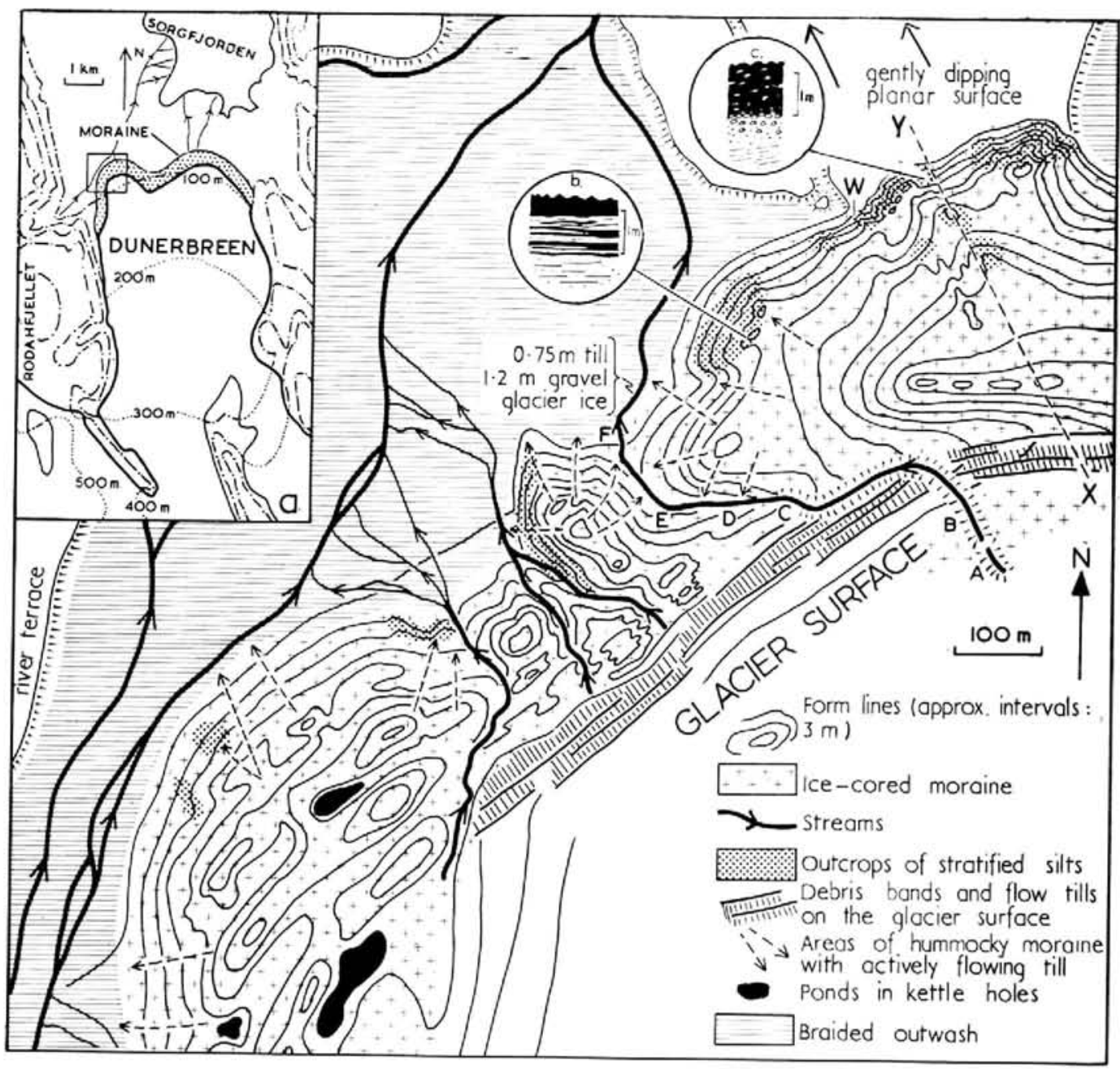

Fig. 2. Map of part of the terminal moraine of Dunerbreen. A section along the stream $A-B-C-D-E-F$ is shown in Figure 3 , and a section along the tine $X-Y$ in Figure 8 . Inset $(a)$ is a map of Dunerbreen showing the location of the area sludied, and (b) and (c) show contacts between the flow till which forms the moraine surface and the underlying silts and sands.

is bounded to the north and west by a broad, braided stream channel which issues from a gap in Rodahlfjellet to the west and flows into the head of Sorgfjorden. Into this channel flow a series of streams which drain the ice front and cut through the terminal moraine into its ice core, revealing the internal structure of the glacier and the origin of the moraine. 
Structure of the glacier ice and its debris load

Figure 3 shows a horizontal section along the line of the deeply cut stream A-F, which is probably situated along a previous extension of the englacial tunnel from which it emerges at point A. Some $200 \mathrm{~m}$ south of A, the ice foliation dips at $7^{\circ}$ towards $160^{\circ}$, progressively increasing in dip in a northerly direction, and becoming $30-40^{\circ}$ towards $150^{\circ}$ north of point $\mathrm{B}$. This increase in dip of the foliation towards the glacier terminus appears to be wholly or in part due to the progressive cutting out of low-angle foliation planes by higher-angle planes. Together with this increase in dip, there is a progressive change in the type of moraine contained within the ice. South of B this consists mainly of large blocks of angular mica-schist and thin $(>2 \mathrm{~cm})$ bands of coarse angular particles, there being little fine-grained material.

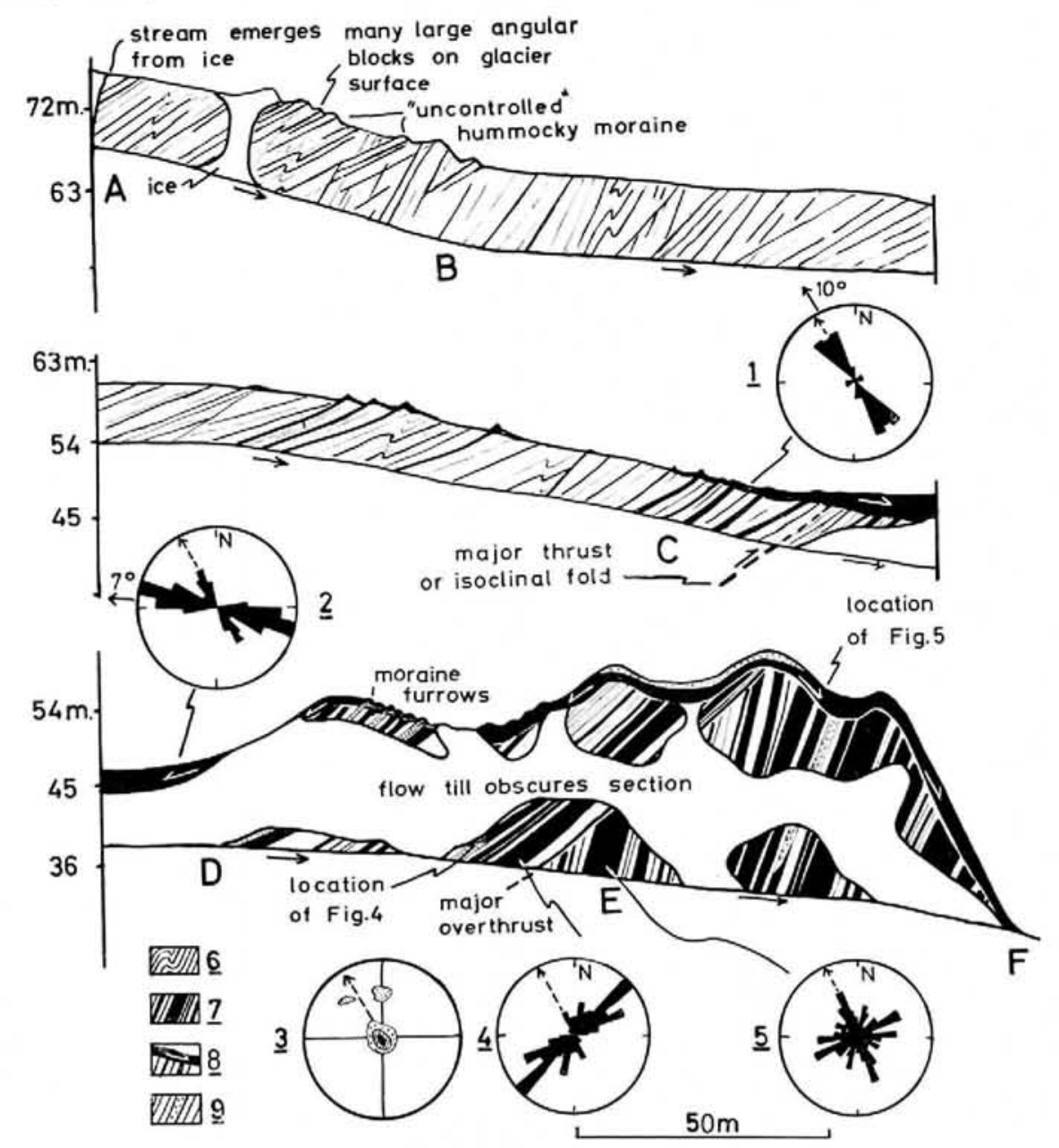

Fig. 3. Section in the south bank of the stream $A-B C-D-E-F$ in Figure 2, showing the development of supraglacial flow till from englacial debris bands. Legend: 1 . Rose diagram showing orientations of long axes of 65 blade- and rod-shaped stones. (Solid arrows indicate the amount and direction of surface slope, and dashed arrows the direction of glacier movement). 2. As above, 78 stones. 3. Equal-area stereographic plot of poles to a-b planes of 87 plate-and blade-shaped slones selected from 4 and 5 . The plane of projection is the plane of ice foliation. Contoured at o-4 per cent, $4^{-8}$ per cent and $>8$ per cent, per $t$ per cent of area. 4. Rose diagram showing orientations of long axes of 74 blade-and rod-shaped englacial stones. 5 . As above, 92 stones. 6. Glacier-ice foliation. 7. Englacial debris bands. Because of the scale of the section, they are somewhat schematized, and angles are exaggerated. 8. Supraglacial flow tills, showing direction of movement. 9. Englacial bands of stratified debris. 
This moraine is probably material which has fallen onto the glacier surface from flanking hills and nunataks in the accumulation area. Its constitution varies at different levels; there is a zone rich in pink quartzite in the vicinity of $\mathrm{B}$ which is distinct from ice overlying it to the south containing dominant mica-schist. Thus the pink quartzites accumulated on the glacier before the schists and they are derived from farther south. North-west of point B, englacial bands, up to $3 \mathrm{~cm}$ thick, of relatively fine-grained silt and sand, occur parallel to the ice foliation, whilst only a few large pink quartzite blocks survive. The bands of fine-grained material have a relatively low ice content, below 60 per cent by volume, whilst the ice between these bands contains a few highly dispersed particles, which are often somewhat coarser than particles in the bands, and sometimes well-rounded, a possible sign of fluvial transport. Thus there is an abrupt change in the type of material carried by the glacier between $\mathrm{A}$ and $\mathrm{B}$; a change from boulders which are probably derived from flanking hills, to finer-grained, often rounded, material which it is suggested is debris derived from the glacier bed. The outcrop of these thin moraine bands on the glacier surface gives rise to small ice-cored mounds and ridges with a thin moraine cover which rarely exceeds ro $20 \mathrm{~cm}$. These mounds and ridges have a very irregular distribution with no discernible pattern.

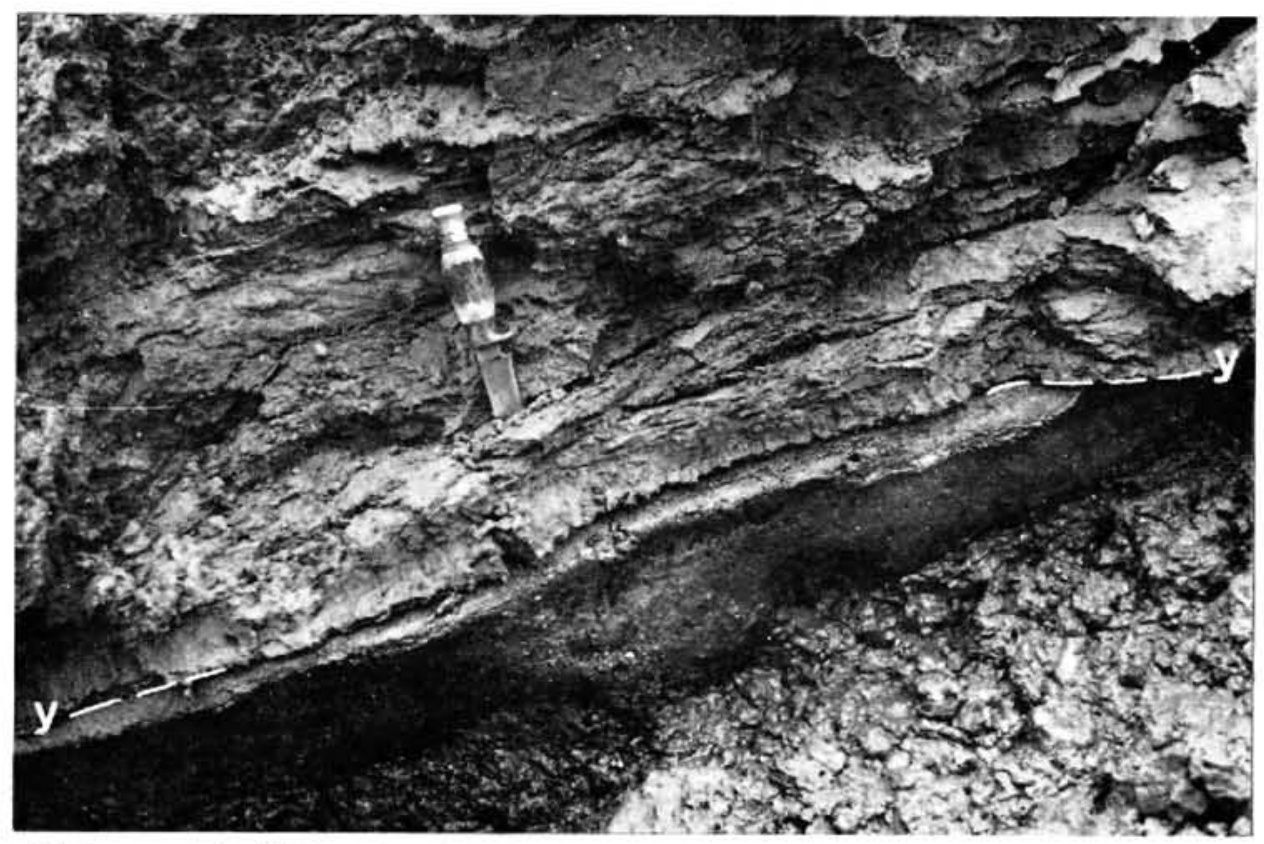

Fig. 4. The lower part of a thick $(1.2 \mathrm{~m})$ englacial debris band of stratified silt and fine sand. The debris/ice contact is marked $y-y$, and the stratification partings can be clearly seen above this and to the right of the knife blade. This stratified debris grades up into zansorted debris in the upper part of the band. The location of this photograph is shown in Figure 3 .

About half-way between B and C, debris bands up to $20 \mathrm{~cm}$ thick composed of silt and sand with some small boulders crop out on the glacier surface, where they stand up as small ridges. When the interstitial ice melts, the material of these ridges collapses and flows down the glacier slope, giving a sporadic cover of flow till. Below $\mathrm{C}$ the glacier surface is completely covered by such flow tills derived from steeply dipping englacial debris bands, and between this point and $\mathrm{F}$ the section can be divided into three parts:

(i) Zone C-D, in which debris bands are up to $0.5 \mathrm{~m}$ thick, and between which there occur thick bands of relatively clean but highly sheared ice containing large angular boulders 
of dark mica-schist, probably of supraglacial origin. The debris bands, which rarely contain more than 40 per cent by volume of debris, consist mainly of silt and fine sand, with some large well-rounded pebbles up to $10 \mathrm{~cm}$ in diameter.

(ii) Zone D-E, in which many of the debris bands are up to $1.2 \mathrm{~m}$ thick, composed of wellsorted and sometimes stratified silt and fine sand (Fig. 4). These silts are very compact and, although they contain bands of ice up to $4 \mathrm{~mm}$ thick, the total ice content is rarely more than $20^{-} 30$ per cent by volume. The ice lying between debris bands contains a small percentage of dirt but it rarely contains any large angular boulders.

(iii) Zone E-F, in which bands of till are very closely packed and up to $5 \mathrm{~m}$ thick, being separated by thin ribs of ice rarely more than $0.5 \mathrm{~m}$ thick (Fig. 5). The amount of ice

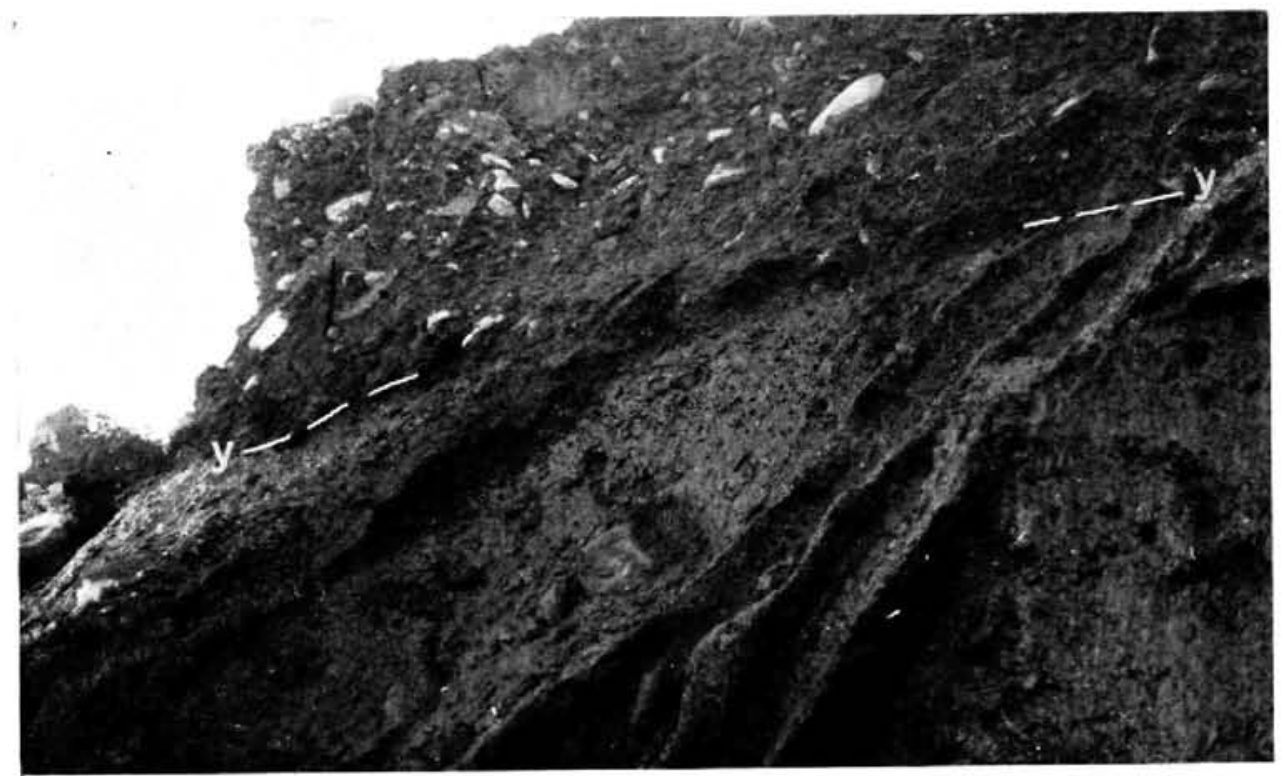

Fig. 5. A t.5 $\mathrm{m}$ thick flow till, derived from englacial debris bands, creeping down the glacier surface which slopes at $15^{\circ}$ to the right (this view is foreshortened). Beneath the till are a series of englacial debris bands separated by relatively clean ice layers which stand out as ribs. The till lice junction is marked $y-y$, and the photograph is located in Figure 3 .

contained within these till bands varies considerably, the fine-grained tills, composed almost entirely of silt, contain as little as 20 per cent of ice, whilst the coarse gravelly tills contain up to 70 per cent of ice. The commonest type, however, is composed of a matrix of silt and sand with sub-angular and sub-rounded pebbles from 8 to $35 \mathrm{~cm}$ in diameter, and occasional very large boulders up to $1.5 \mathrm{~m}$ in diameter; the ice content is approximately $40-45$ per cent by volume. Pebbles and boulders are mainly of pink and grey quartzite, and light and dark grey mica-schist; they are generally rounded and blade-shaped, and the larger ones are striated. Some of the silty englacial bands show a structural foliation parallel to their bounding ice walls. A major overthrust occurs in this zone, whereby debris-rich ice is thrust over ice with more steeply dipping debris bands, the latter being truncated by the thrust. There is very little debris located along the thrust plane.

The lower part of this sequence of englacial moraine, described in (ii) and (iii) above, appears to be entirely derived from the glacier bed, whilst some of the material in the zone 
C-D, described in (i) is probably derived from the glacier surface. South of point $\mathrm{C}$ this sequence of ice with basally derived debris overlain by ice with surface-derived moraine is repeated, a structural duplication which could be a result of folding or thrusting near point $\mathrm{C}$. This hypothesis is incorporated in Figure 3 . Thrusting is actually observed at locality E where ice containing debris bands dipping at $35^{\circ}$ towards $140^{\circ}$ is thrust over debris-rich ice dipping at $65-80^{\circ}$ towards $135^{\circ}$. Orientations of pebbles in till bands were measured at two localities above and below this thrust and they are plotted on rose diagrams (4) and (5) in Figure 3. If the moraine is assumed to trend at right-angles to the direction of ice movement, and if the dip of the ice foliation is assumed to be approximately parallel to the direction of movement, blade- and rod-shaped particles above the thrust show an orientation maximum transverse to the direction of ice flow, whilst particles below the thrust show peaks parallel and transverse to this direction, although these peaks are only just distinguishable above a background in which long-axis orientations occur in all azimuths. An interesting point is illustrated in the stereogram (3) in Figure 3 , which shows that the $a-b$ planes of blade- and plate-shaped boulders are parallel to the bounding walls of the debris bands in which they are contained and to the icefoliation planes. If one assumes that ice flow takes place parallel to the ice-foliation planes, there is thus little or no imbrication of the $a-b$ planes with respect to flow.

\section{The occurrence and origin of supraglacial flow tills}

North of point $\mathrm{C}$ in the section $\mathrm{A}-\mathrm{F}$, the glacier surface is completely covered by a variable thickness of sediments, largely consisting of till derived from debris bands in the underlying ice. As seen in Figure 2, the form of this surface moraine consists of a large number of ridges lying roughly parallel to the ice margin, between which there are furrows and kettle-holes, and channels often with stream deposits. The greatest thicknesses of till appear to lie in the furrows between ridges, the maximum proven thickness being $5 \mathrm{~m}$.

If a till sheet builds up on the glacier surface at a particular point, and provided that it is not thick enough to stop ablation of the underlying ice, material is added to the base of this till sheet from thawing englacial debris bands. This process is illustrated in Figure 5 which shows a thick $(\mathrm{I} .5 \mathrm{~m})$ supraglacial flow-till sheet which has thawed out completely and is slowly creeping down an ice slope of about $15^{\circ}$. The underlying ice contains a series of debris bands dipping at about $65^{\circ}$ which have the same composition as the overlying flow till, and in which stones are orientated with their long axes and $a-b$ planes in the plane of the debris bands. In the basal part of the surface till, long axes and $a-b$ planes have a similar orientation to those in the underlying debris bands, but at progressively higher levels this orientation changes until in the uppermost $1 \mathrm{~m}$ of the till long axes are orientated in the direction of greatest surface slope, and dip down-slope at about $5^{\circ}$ (note that these long axes are thus imbricated up-slope, as the surface slope is $15^{\circ}$ ). Thus the lower part of this surface till contains fabric elements which are the result of englacial shearing, whilst the fabric of the upper part of the till is related to down-slope creep.

In those areas where the surface till creeps down-slope, there is no surface expression of the debris bands which lie in the ice beneath the till. However, on many flat areas of the terminal moraine, where there is little down-slope movement, the surface is traversed by a series of ridges and furrows with a relief of up to $1 \mathrm{~m}$, which trend parallel to the strike of the debris bands in the underlying ice (Fig. 6). One such area lies immediately above the western slope of the channel $\mathrm{A}-\mathrm{F}$ and is marked in the section in Figure 3. An excavation showed that each one of the ridges represents the outcrop of an englacial debris band projecting above the glacier surface. The great majority of thin ridges consist of till, but the dip of the stratification has however decreased below its englacial angle of $45^{\circ}$, as the silt-debris ridge has deformed and is beginning to flow down-slope. (This bending over of debris bands which project above the glacier surface is a common phenomenon.) The outcrops of many such debris bands on the glacier surface give rise to flows of stratified sand and silt. 


\section{Modes of flow of supraglacial till}

Although much of the supraglacial till cover is probably temporarily stationary, or so slow moving as to be imperceptible over a period of several days' observation, other parts move at rates varying from a slow creep, which is measurable over several days, to a perceptible flow, at rates up to several metres per minute. Down-slope movement of till takes place in several ways:

(i) Till lying on relatively well-drained slopes may creep slowly down-slope as a thick sheet (as shown in Figure 6). The base of the till flow acts as a shear plane and there appears to be little differential flow within the till, although some must take place to produce re-orientation of till stones. If a till lying on the glacier surface is frozen at the base, no movement takes place, but, if the till is entirely unfrozen and the underlying glacier surface is ablating, movement does take place, the till/ice interface acting as a basal shear plane. Stone-orientation measurements in two such tills (Fig. 3, I and 2) give strong orientation maxima parallel to the direction of surface slope; there also appears to be an up-slope imbrication of $a-b$ planes of blade- and plate-shaped stones.

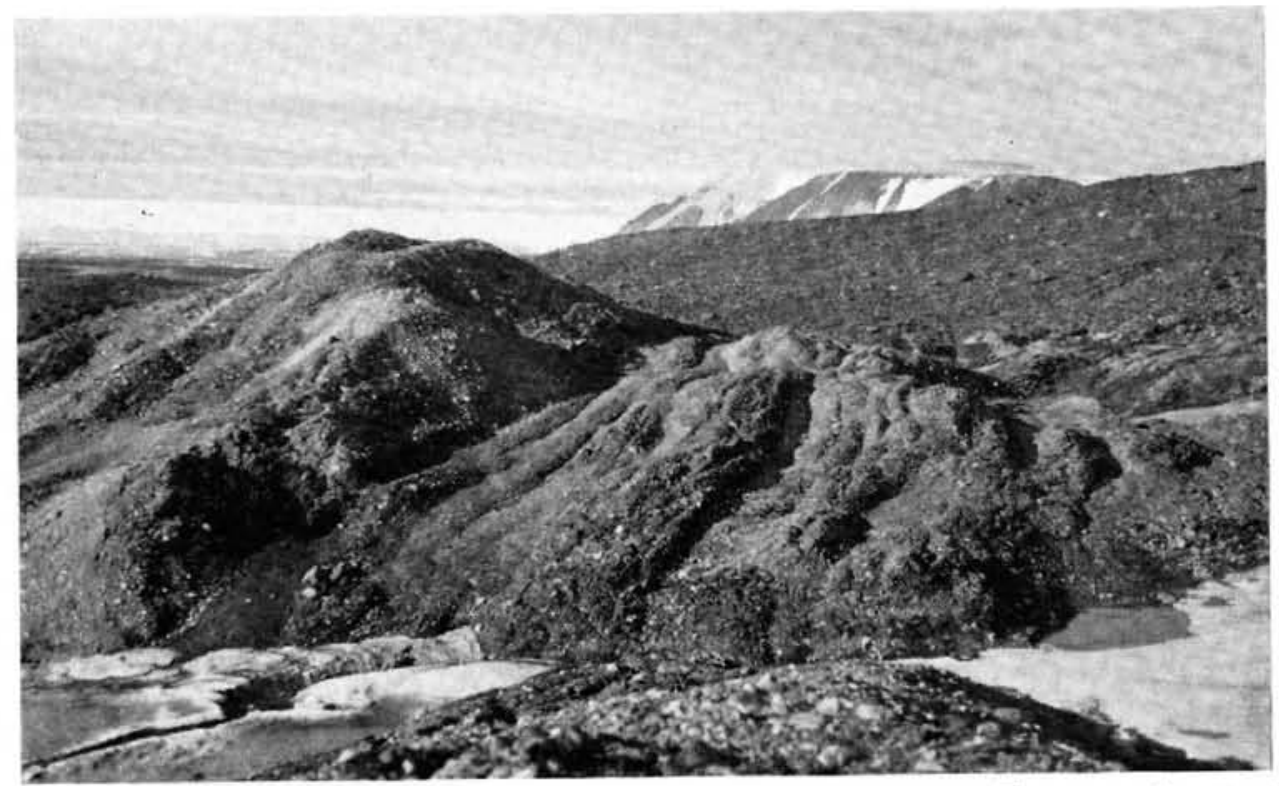

Fig. 6. A series of furrows in the supraglacial till on a flat area of the moraine of Dunerbreen. They are a surface expression of debris bands which project above the underlying ice surface. The furrowed belt is $25 \mathrm{~m}$ wide.

(ii) Till may move down-slope as a rapidly moving, fluid tongue. The melting out of debris bands to give a supraglacial till releases a considerable amount of water, as does ablation of ice beneath such a till. If drainage is impeded, as occurs in hollows, on flat areas or very low-angle slopes, the till becomes waterlogged and small pools often occur on its surface. Although such tills are extremely unstable, it is only when they occur on slopes that flow takes place, or when a flat area of till lies at the top of a slope. In the latter case it is common for rotational slumping of the till over the underlying ice surface to occur at the top of the slope, producing arcuate coombe-like slump hollows, the till in the back walls of which is continually slumping down to produce rapidly moving, and overlapping tongue-shaped flows which may be up to $1 \mathrm{~m}$ thick. Such an occurrence is shown in Figure I I. In general, long axes of stones in the body of these 
flows lie parallel to the direction of movement, although many have a steep dip, whilst those at the front of the flows lie transverse to movement. Differential movement within the body of these flows appears to be important.

(iii) A third type of flow occurs on the surface of waterlogged tills, such as those mentioned in (ii) above. These are very thin (up to $10 \mathrm{~cm}$ ), move very rapidly down the lowest slopes $\left(1-2^{\circ}\right)$, and in extreme cases give rise to mud-transporting streams. They are capable of transporting stones up to $30 \mathrm{~cm}$ in diameter.

Of the three types of flow referred to above, (i) was only seen moving over an ice surface, whilst (ii) and (iii) were also noted flowing over the surfaces of other stable sediments. The factors which appear to govern the type of flow are: grain-size of the material, water content, whether the ice/till interface is frozen, and topographic position. Coarse bouldery tills containing little silt or fine sand tend to be fairly stable, only moving by slow creep on steep slopes, whilst sandand silt-rich tills move down the lowest slopes, the latter more readily.

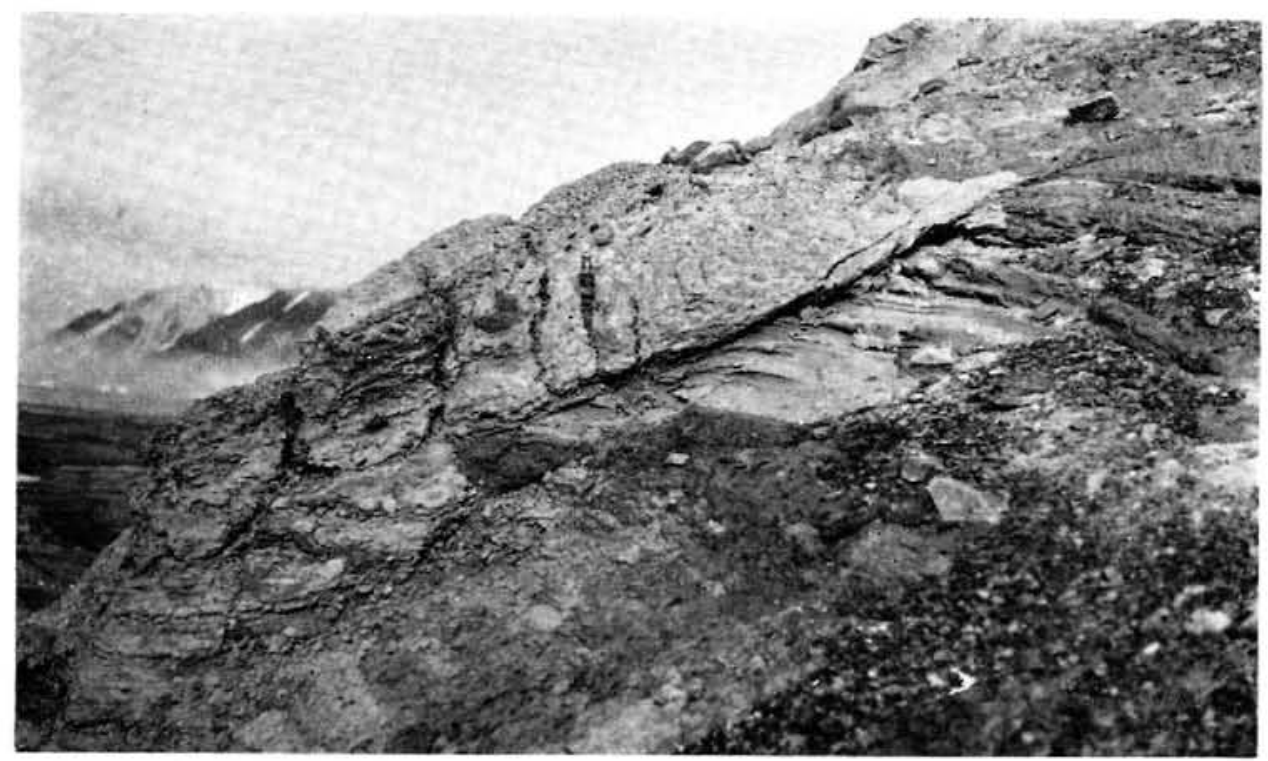

Fig. 7. A thin flow till (the knife stands just above its base) which has flowed over the stratified deposits in the moraine front of Dumerbreen. The bedding in the underlying silts is truncated but not disturbed. Most of the faults in the sills are trumcated by the base of the till, although one fault at the left-hand side of the photograph cuts both till and silt.

\section{Flow tills associated with stratified deposits in the moraine front}

The till sheet which is currently forming on the glacier surface can be traced down the fore-slope of the moraine and onto the bed of the broad channel which borders the moraine to the north. At the point where the stream A-F debouches onto the floor of this channel, a section is exposed which shows $0.75 \mathrm{~m}$ of till overlying $1.2 \mathrm{~m}$ of stream gravels. At the southern end of the section, these stream gravels overlie glacier ice. Areas of such surface till overlying gravel are common in the immediate proglacial zone of the glacier, and over wide areas at the head of Sorgfjorden, and are likely to have had a similar origin, having flowed down the foreslope of the glacier.

The surface flow till on the terminal moraine is in many places still active, and it is easily remobilized by melt water to form flows which move freely over the surface of the moraine. This flow till is exposed in many places in the cliffs on the north-westerly flank of the moraine where it is at least $3 \mathrm{~m}$ thick in parts, and overlies stratified silts and sands which have a 
maximum proven thickness of $15 \mathrm{~m}$, but a probable maximum of $24 \mathrm{~m}$ (see Figure 2 and the horizontal section through the moraine in Figure 8). The capping of till on bedded deposits is not a local phenomenon occurring only at the frontal margin of the moraine, but can be found at considerable distances back from the front. The till is grey, silty and contains abundant sub-rounded, often striated pebbles up to $30 \mathrm{~cm}$ in diameter, its degree of compaction varying with the grain-size of the constituent materials, silt-rich parts being well compacted, coarser parts less compact. Figure 7 and insets (b) and (c) in Figure 2 illustrate three different types of junction between this till and the underlying bedded sediments. In Figure 7 a thin surface till is seen truncating the bedding in the underlying deposits; in Figure 2 (c), the till/ bedded sediment junction is a gradational one; whilst in inset (b) the main till horizon lies conformably upon the underlying silts, in which thin bands of till occur for a thickness of $1.2 \mathrm{~m}$ below the main till. The majority of till/stratified sediment junctions, however, are sharp planar interfaces.

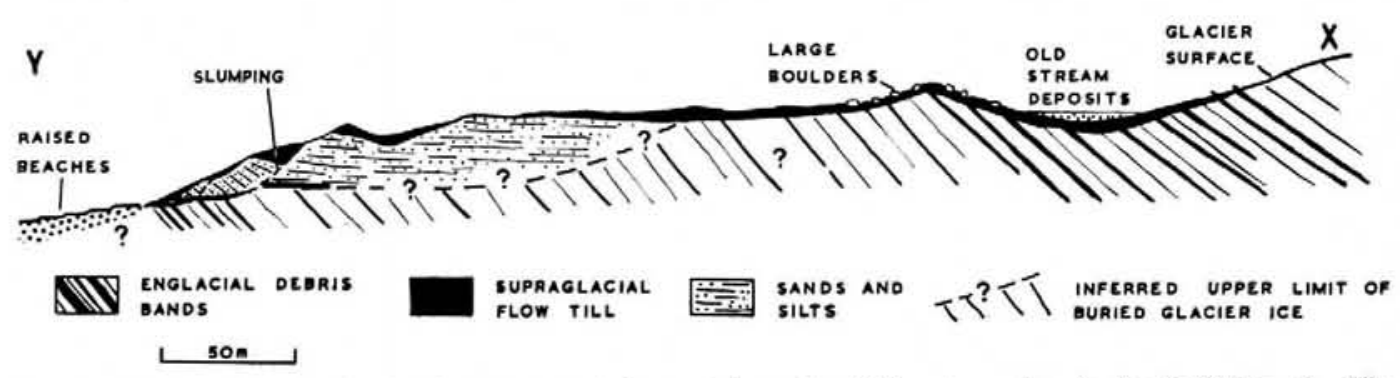

Fig. 8. A horizontal section showing the structures of the terminal moraine of Dunerbreen along the line $X-Y(F i g .2)$. The section is based on surface observations alone. The full till-bedded sediment-till sequence, lying on the glacier ice, is actually exposed at the moraine front.

The bedded sediments beneath the till capping consist predominantly of grey and greybrown silts with some sand and gravel. They form an essentially uniform sequence of planar, laminated graded beds of micaceous silts $(>0.001 \mathrm{~mm})$ with individual graded units ranging down to $3 \mathrm{~mm}$ in thickness. The lower part of the sequence is generally coarser, fine sand being an important component. There are a few beds of gravel up to $30 \mathrm{~cm}$ in thickness, and occasional isolated pebbles (up to I $5 \mathrm{~cm}$ ) occur within the silts, the bedding in which "flows" around the pebbles. Beds showing slightly asymmetric ripples also occur, although crosscutting beds of fine sand and sandy silt are rare. At several levels there are layers of mosses which, though obviously derived, are extremely well preserved. Fragments of marine molluscs also occur within the sequence. At the base of the bedded sediments, at point $\mathrm{W}$ on the map in Figure 2, lies a thin $(1 \mathrm{~m})$ till which overlies stagnant glacier ice containing debris bands. Over much of the moraine front the bedding in the sediments is approximately horizontal but in places there are dips up to $40^{\circ}$, generally in a southerly direction. These appear to be due to rotational slumping along inclined slip planes striking parallel to the moraine front, and associated with them the silts are in places cut by a close pattern of high-angle joints, many of which show signs of vertical movement; jointing is sometimes so intense as to produce a brecciated effect. The gently warped bedding, related to major slip planes, and the jointing both indicate vertical collapse as a result of slumping down the steep cliff face, although some may be due to melting or settlement of the glacier ice which demonstrably underlies these sediments. There are no folds or fractures which might indicate lateral translation as a result of ice pushing.

The gently dipping planar surface near point Y (Fig. 2) is cut by a number of raised beaches, the topmost occurring at a height of $30 \mathrm{~m}$. These are part of the system of raised beaches in this area, which reach up to $5^{\circ}$ to $65 \mathrm{~m}$ above sea-level and were formed in the 
period of progressively lowering sea-level from at least to ooo years B.P. (Blake, 1961) to the present day. Thus it is possible that the bedded sediments in the moraine cliff are marine in origin, related to a higher sea-level, and that a change in the pattern of marine erosion and deposition during subsequent lowering of sea-level resulted in destruction of most of the deposit of which the sediments in the moraine front formed but a small part. Another possibility is that the deposits have been pushed into their present position by the bulldozer action of the glacier, and that they were originally deposited either in a hollow on the glacier surface, of which the present moraine front formed the edge, or proglacially but above sea-level. However, the lack of any structures indicating lateral pushing seems to make this unlikely. It is hoped that ${ }^{4} \mathrm{C}$ determinations, currently being undertaken, on the mosses in the moraine front and on material from the raised beaches, will solve the problem of the environment of deposition of these sediments.

Whatever this environment may have been, it is clear that it was open, and that flow tills derived from englacial debris bands moved into it whilst deposition was still taking place, as indicated by the till/bedded sediment interdigitations shown in Figure $2 \mathrm{~b}$. The great mass of flow till was, however, emplaced over these sediments after accumulation of the latter had ceased, in the same way that the supraglacial till at the northern end of the section A-F is flowing out over the outwash sands and gravels to the north. The fact that the lower supraglacial till beneath the bedded sediments at point W (Fig. 2) overlies but is not overlain by glacier ice suggests that it was deposited as a flow till before the bedded sediments were laid down.

The sequence of till-bedded sediments-till exposed in the terminal moraine of Dunerbreen is however most interesting in that it is entirely of supraglacial origin, and demonstrably not the product of two glacier advances separated by a retreat. The thicknesses of the different elements of this sequence are comparable with the thicknesses found in Pleistocene sequences. Since the upper till is at least $3 \mathrm{~m}$ thick, the bedded sediments at least $15 \mathrm{~m}$, and even if the thin lower supraglacial till is discontinuous, it is likely that the underlying ice, which contains a considerable volume of debris, would give rise to a thick lower till if the climate were to ameliorate and this buried ice were to melt out.

\section{VALhaLlfonna}

Valhallfonna is the north-easterly extension of Asgardfonna, and terminates in Hinlopenstretet in a series of ice cliffs $25 \mathrm{~km}$ long (Fig. I). The northern margin of Valhallfonna trends in a west-east direction across the plain of Basissletta until it intersects the coastline. This glacier lobe on Basissletta is slow-moving, with a low surface gradient, and near its front a series of englacial debris bands, striking parallel to the glacier margin, rise up and crop out on the glacier surface, producing extensive flow tills (Fig. 9). This relatively slow-moving lobe is distinctly separated by a zone of intense shear from a fast-moving, highly crevassed glacier stream which flows in a depression to the south and into Hinlopenstretet, giving rise to the most northerly $3.5 \mathrm{~km}$ of the ice cliffs referred to above. The debris contained in this glacier stream lies close to the glacier bed.

At the eastern end of the northern margin of Valhallfonna the lower part of the flow-tillcovered fore-slope of the glacier has, in many places, a hummocky surface form and at one point (Fig. 9) it has been dissected by outwash streams to reveal a number of deep sections. These sections show that the surface flow till on the lower part of the glacier fore-slope does not lie directly on glacier ice, but covers a sequence of stratified deposits and older tills which themselves lie on glacier ice. The inset in Figure 9 shows a map of this dissected area on the lower hummocky part of the glacier fore-slope, which is essentially a hummocky ice-cored moraine, and Figure to shows a west-east section across it. Small remnants along the foot of the glacier fore-slope suggest that hummocky moraine was widespread along it but it has been largely destroyed by processes of mass wasting and fluvial erosion. 
The dissected hummocky moraine area

The deposits which make up the block $\mathrm{M}$ (inset in Figure 9) are draped over an irregular ice surface, and show a sequence of till-sand and gravel-till (Fig. 10). Sections on the northeastern side of this block at $\mathrm{R}$ show the ice beneath the lower till to be well foliated, containing many thin bands of sandy silt $3-5 \mathrm{~cm}$ apart, the concentration of debris within this ice being not more than 5 per cent by volume. The lower till is $2 \mathrm{~m}$ thick and it is a black-grey silt (grey on drying out) containing some pebbles and often perfectly preserved marine shells, which are common throughout, particularly at the top. The basal $30 \mathrm{~cm}$ of the till, however, is composed of black sandy silt having a structural foliation parallel to the underlying ice surface, and containing neither shells nor pebbles. The sands and gravels which overlie the till are very variable in character, the gravels being composed of sub-angular to sub-rounded

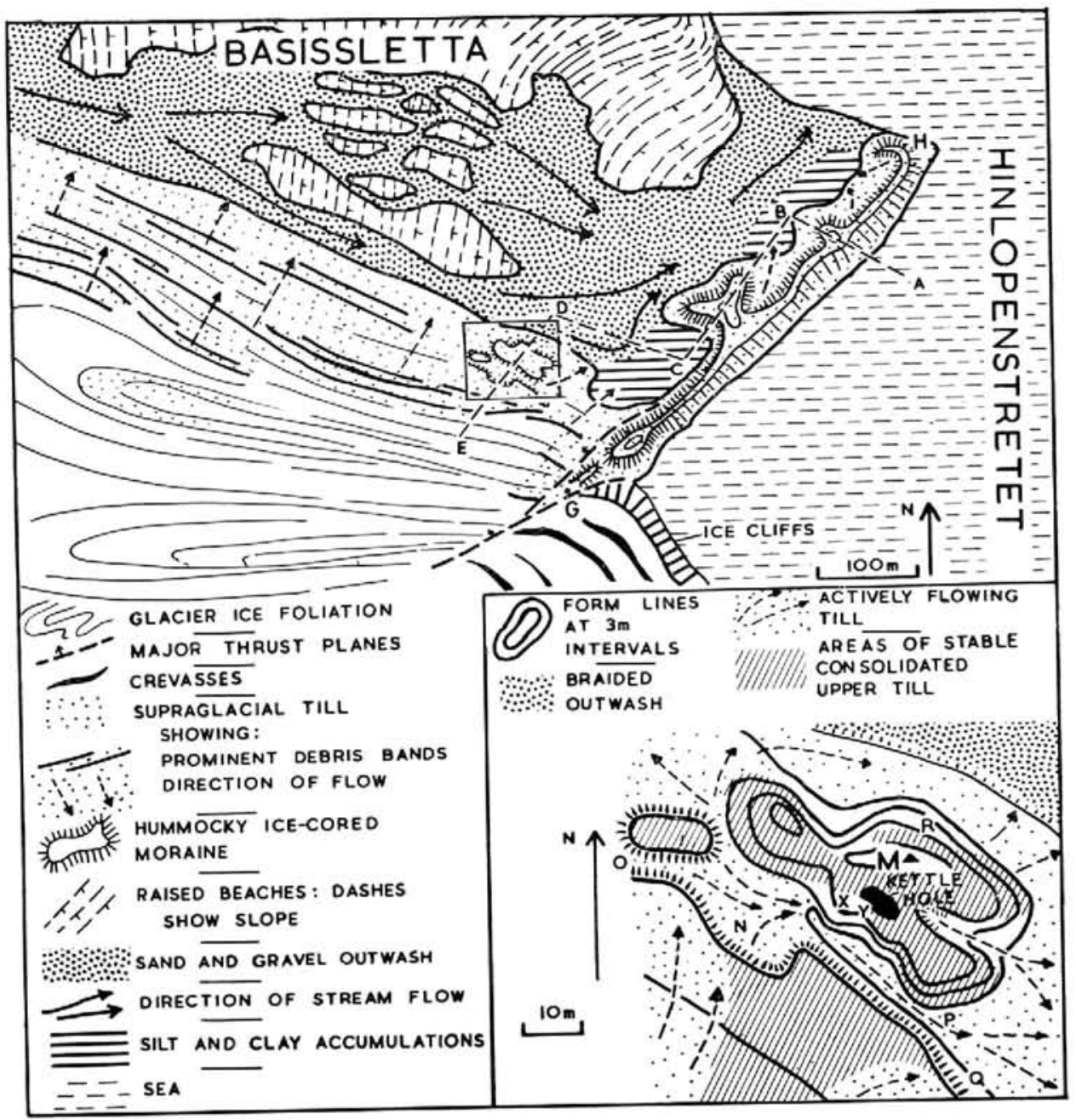

Fig. 9. Map of part of the northern margin of Valhallfonna (Fig. I) and its supraglacial and proglacial sediments. The inset is

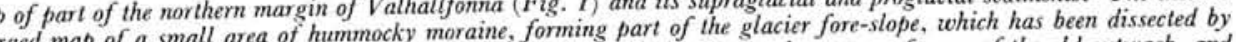
outwash streams. Figure to shows a section along $A-B-C-D-E$. The hummocky nature of some of the old outwash, and exposures of dead glacier ice, indicate that much of the proglacial area is underlain by glacier ice, the extent of which is very difficult to determine. 
boulders up to $30 \mathrm{~cm}$ in diameter, which are rarely striated and contain abundant comminuted shell fragments. The bedding in the sands and gravels is warped into a broad syncline and anticline, and in the upper part, at a height of $24 \mathrm{~m}$ above sea-level, there are two prominent organic beds, both $3-6 \mathrm{~cm}$ thick and containing carbonized marine algae, and shells in all states of preservation. The uppermost organic bed contained a fragment of whale bone. It seems likely that these organic beds were laid down on strand lines during a period in which sea-level was considerably higher than at the present day, and that the associated gravels and sands are beach deposits. This is substantiated by a $4 \mathrm{C}$ age determination on the algae, of $9125( \pm 161)$ years B.P., at which time it is thought that sea-level in this area was approximately $25-30 \mathrm{~m}$ above present-day sea-level. The fact that the lower till overlies but is not overlain by ice, together with its similarity in texture to the tills of Dunerbreen, suggest that it is a flow till, which has either flowed directly into the sea or was inundated by the sea, represented by the beach gravels, after deposition. The preservation and position of life of the boring molluses within the till, support the idea that it was submarine at one stage. The absence of shells in the basal $30 \mathrm{~cm}$ of this till, and its similarity in composition to the material contained within the underlying ice, suggests that this basal $30 \mathrm{~cm}$ has accumulated in situ by ablation of the underlying ice. Some of this ablation may have occurred generally at the ice/till contact at an earlier period when the overburden was much thinner, but it is unlikely to have occurred beneath the present overburden of $9 \mathrm{~m}$. Much of the ablation is probably due to the exposure of the ice/till contact on the cliff face.

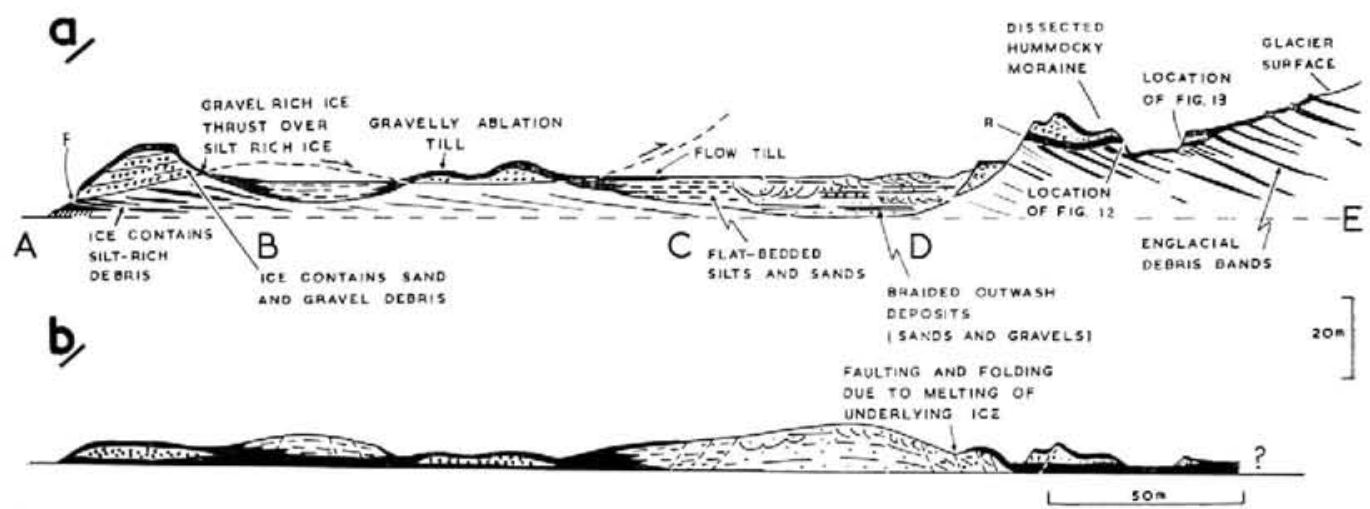

Fig. 1o. a. A section along the line A B C-D-E (Fïg. 9) inferred from surface observation. b. A hypothetical section showing the possible sequence of depasits which might restilt if the buried glacier ice in $(a)$ were to mell out. Both sections viewer from the north.

To the south-west of the above section (see the inset in Figure 9), a widespread till overlies the gravels. It varies in thickness from o to $2 \mathrm{~m}$, being thickest in hollows and forming the bed of a kettle-hole. On steep well-drained slopes the till is dry and overconsolidated, whereas on low slopes, flat areas and hollows it is saturated. Where such saturated tills lie above the steep margins of the block, a considerable amount of till flows down these margins onto the surrounding lower ground forming a morass of fluid till. At point $\mathrm{Z}$, a considerable amount of till has slumped down-hill over the underlying ice surface leaving a coombe-like hollow from which a series of overlapping till flows issue (Fig. 11). The hollow N (see inset in Figure 9) appears to be another slump hollow of this type.

The stratigraphical equivalent of the section exposed at R (see inset in Figure 9) is well exposed on the south-western side of the block $M$ between $X$ and $Y$ and is shown in Figure 12. The lower till does not contain any shells and it lies directly on glacier ice containing a large number of debris bands dipping up-glacier at $10^{-2} 20^{\circ}$ to $200^{\circ}$. These lens out both down dip 


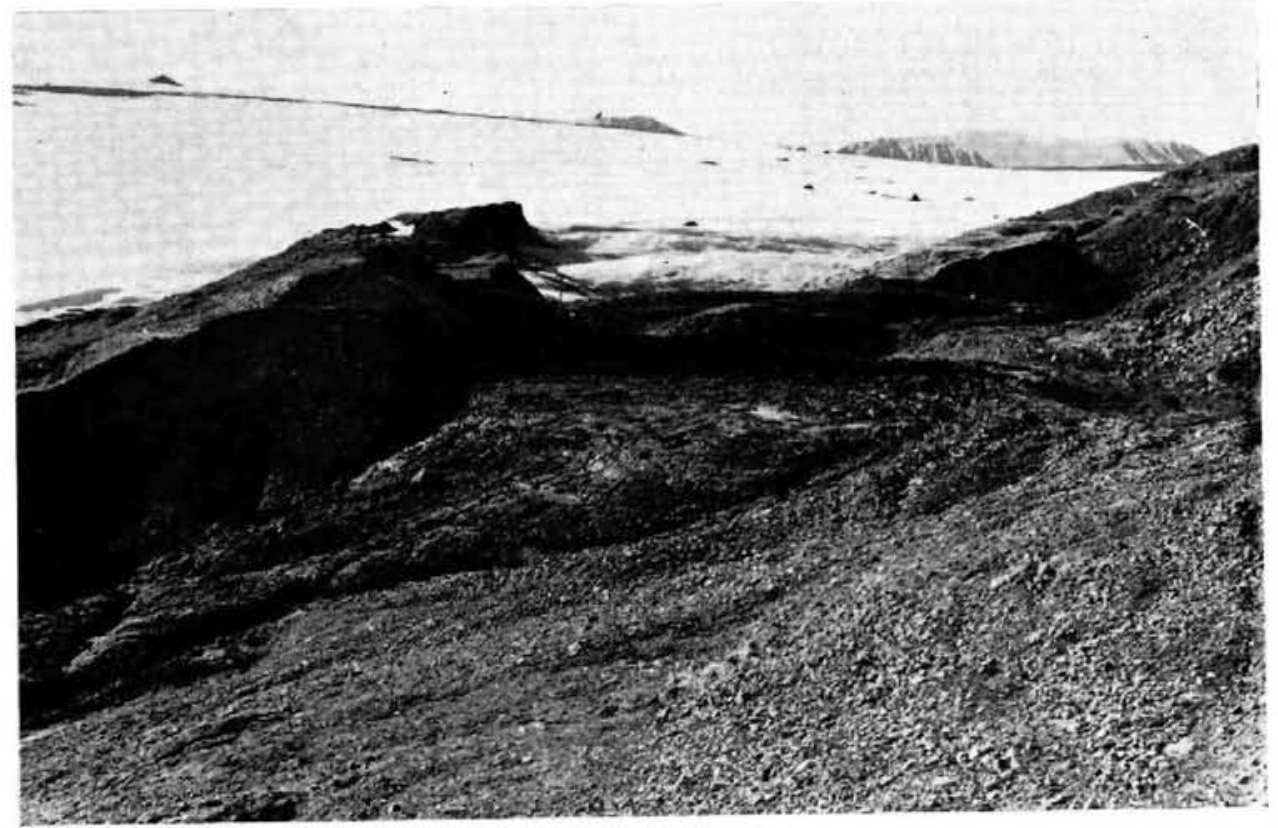

Fig. II. A hollow at point $Z$ in Figure 9, produced by slumping of the supraglacial sediments over the underlying ice surface. The flow emerging from the hollow is highly fuid, moving perceptibly at about $1 \mathrm{~m} / 5 \mathrm{~min}$. An ice-axe in the headwall provides a scale.

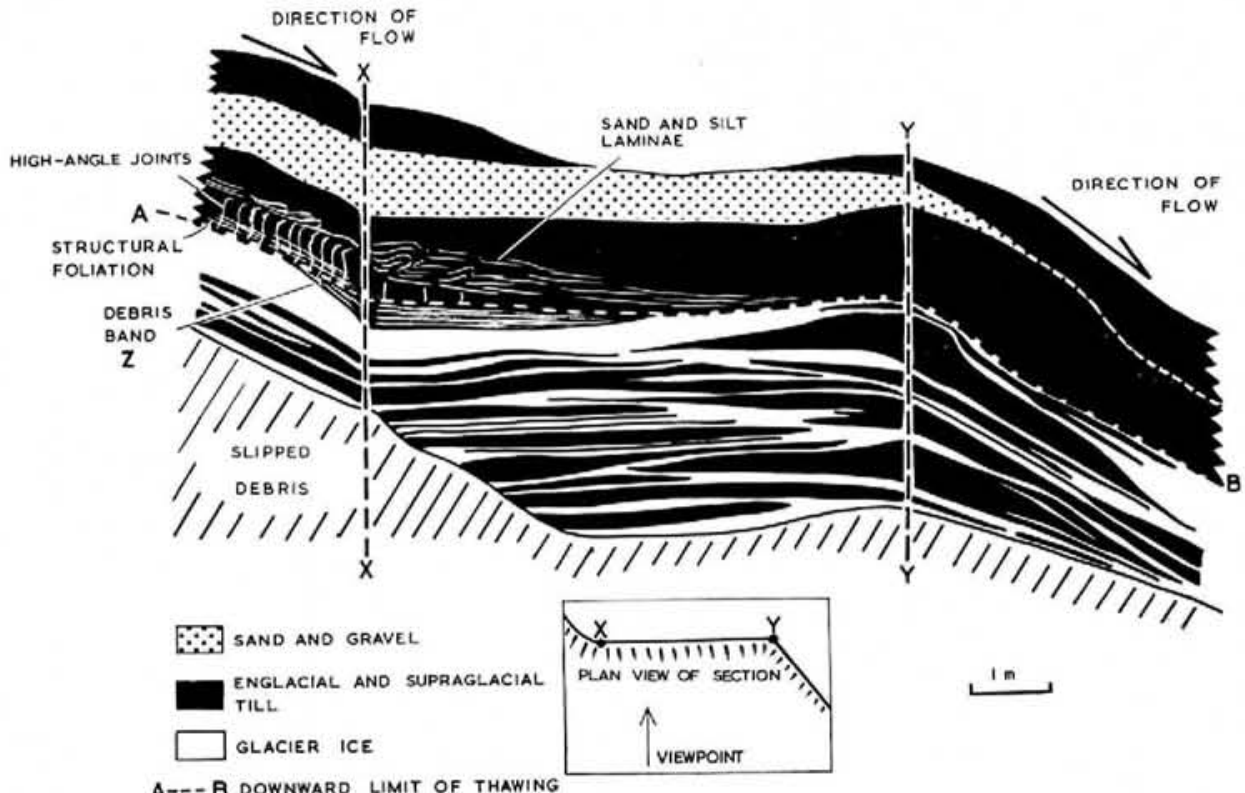

Fig. I2. A section in the dissected hummocky moraine area showing the upper and lower flow tills, separated by sands and gravels, overlying debris-rich glacier ice (along the line $A-B$ ). Dashed lines $X-X$ and $Y-Y$ are located at points $X$ and $Y$ in Figure 9 . 
and along the strike, where they are replaced laterally by others. Above the lower till, the lateral equivalent of the gravels at $\mathrm{R}$, is a series of sands with some gravel but no organic beds. The upper till has a sharp conformable interface with the underlying sands, the bedding in which is undisturbed.

The section in Figure 12 also illustrates the way in which englacial debris can be released from the ice without undue disturbance of its structure. The debris band $\mathrm{Z}$ is overlain by unfrozen till. Although the upper part of this till is a flow till, the basal $25 \mathrm{~cm}$ appear to have been derived from debris band $\mathrm{Z}$ by the thawing of its interstitial ice, and it has a structural foliation parallel to the underlying frozen surface. This foliation was seen in several other tills which appear to have thawed out in situ from englacial debris bands. Seen in a section parallel to the $45^{\circ}$ slope of the underlying ice surface (to the left of X in Figure 12), the foliation in the bottom part of the basal till is cut by a series of joints which rest on the frozen surface

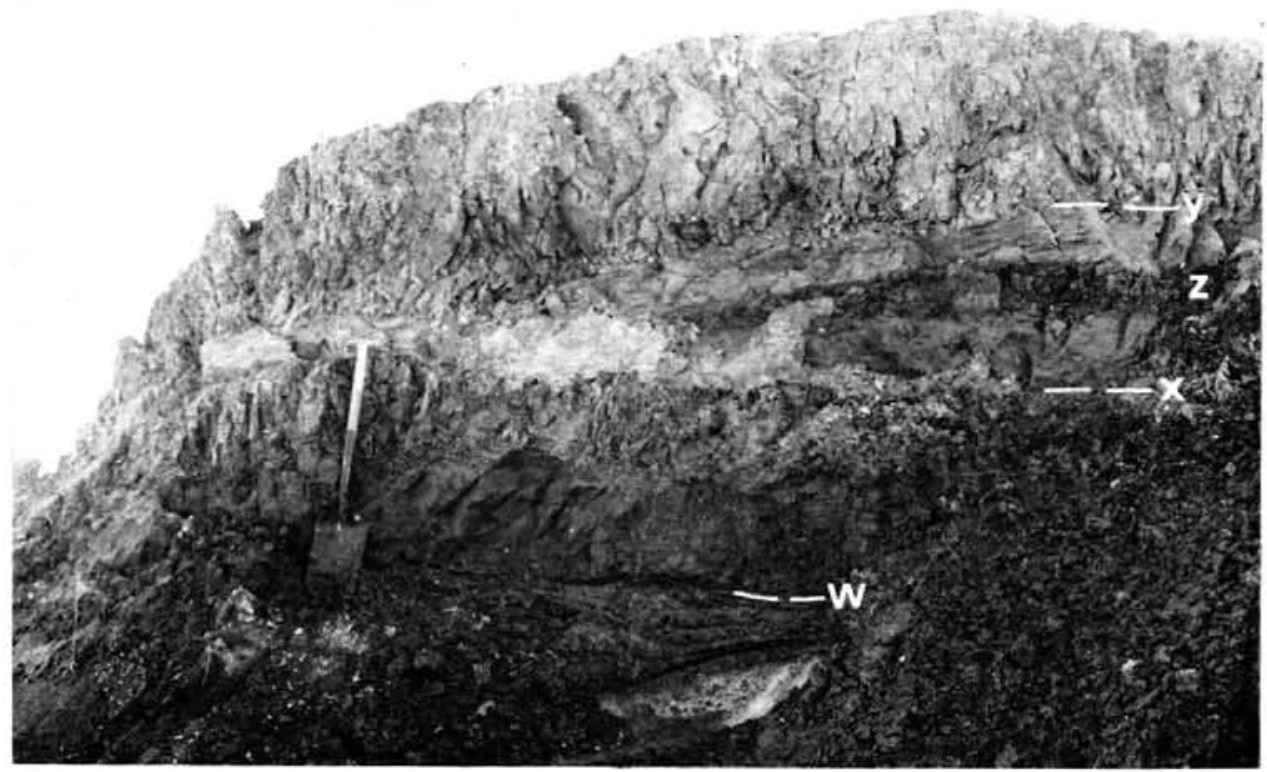

Fig. 13. The sequence of lower till $(0.9 \mathrm{~m})$; middle sands, silts and clays $(15 \mathrm{~cm}$ to $0.85 \mathrm{~m})$; and upper till $(0.9 \mathrm{~m})$ overlying debris-rich glacier ice, exposed in the back wall of the hollow $N$ (see inset on Figure 9). The lithological boundaries are marked $w, x$ and $y$. Note the thickening to the right of the stratified sediments which include a prominent band of clay (marked z), the regular jointing in the lower till, and the complex jointing in the upper till and the upper part of the lower till which is probably related to drying out.

beneath. These trend normal to the slope of this frozen surface, they are approximately vertical, though sinuous in section, and are strictly parallel and evenly spaced at $3 \mathrm{~cm}$ intervals. Approximately $0.5 \mathrm{~m}$ above the frozen surface, the joints are cut out by a series of wisps of sand within the till which form a series of flat-lying isoclinal folds. The near-vertical joints within the till probably result from slight movement of the till over the underlying frozen surface, but they appear to have been destroyed at the level of the sand wisps by relatively rapid flow. It is probable that this flow took place at the surface, each isoclinal fold nose possibly representing a single thin mudflow. The sandy wisps which delineate these folds could have been derived direct from the parent debris band or picked up as the flow moved over an area of sand.

The tripartite sequence of till-bedded sediments-till is also widely exposed on the southwestern side of the channel O-P (see inset in Figure 9). Figure $\mathrm{I} 3$ shows a section at the back 
of the hollow $\mathrm{N}$, where $0.9 \mathrm{~m}$ of till are overlain by $0.2-0.85 \mathrm{~m}$ of silt and fine sand and a further $0.9 \mathrm{~m}$ of till. The basal till immediately overlying the glacier surface is a brown sandy silt containing wisps of clay and occasional pockets of pebbles. This is also cut by a number of prominent joints spaced at regular (10 cm) intervals, dipping at $45^{\circ}$ to $110^{\circ}$ (down-slope) and making an angle of approximately $45^{\circ}$ with the underlying ice surface, the direction of slope of which is not determinable (Fig. 13). Normal fault movement along these joints is indicated by the displacement of the wisps of clay within the till. Joints such as this are common in clay sediments moving by slow creep (Sharpe, 1938), and the fact that they continue into the overlying beds probably indicates that the whole sequence has moved by slow creep over the ice surface. The joints continue into the overlying bedded deposits where they steepen to $85^{\circ}$ and become indistinct, being truncated by another set which dip at $65^{\circ}$ to $020^{\circ}$. The latter can be traced into the upper till where it is lost in an extremely complex joint system. The upper till overlies the bedded deposits with a sharp conformable junction, and there is no sign of disturbance in the beds immediately below this junction. The till is a completely unsorted mixture of silt, sand and gravel, in contrast to the finer-grained lower till, and it is clearly derived from debris bands which crop out as series of low west-east trending ridges on the glacier surface to the south. Till derived by melting and slumping from these ridges flows down the glacier surface and is currently accumulating as a surface till on the southern side of the channel O-P. In those places where deposition is not currently in progress, the till has partly dried out and is overconsolidated. The part of the upper till shown in Figure 13 is partly dried out in this way. The surface of this till shows a polygonal joint pattern, probably related to drying out (Corte and Higashi, 1964), the complex jointing observed in section being the sub-surface expression of this polygonal joint pattern. Where the upper till is silty and fairly homogeneous, the pattern of jointing is regular, but where the till is poorly sorted it is extremely irregular, and often controlled by pebbles within the till. Traced to the north-west from point $\mathrm{N}$ the upper till fails, and the underlying stratified deposits thicken to $2.2 \mathrm{~m}$ of well-bedded sanc's with ripple markings, ard include beds of laminated clay and silt up to $15 \mathrm{~cm}$ thick. The lower till and overlying stratified deposits, however, lens out in a southerly direction, as the ice surface rises and eventually it underlies the uppermost till (Fig. Ioa).

In the embayment $Q$ (see inset in Figure 9) a series of poor sections were excavated which demonstrate the way in which the thickening of the upper till in a north-easterly direction, down the glacier surface, is related to the outcrops of debris bands on the interface between till and underlying glacier ice. They also show a change in character of the englacial debris near the letter $Q$ in the inset in Figure 9. The silt and fine sand debris is replaced upwards by a series of bands containing very variable and unsorted debris ranging from pebbles $15 \mathrm{~cm}$ in diameter to coarse and fine sand and silt. This contrast between the upper and lower series of debris bands is similar to the contrast between the upper and lower supraglacial tills.

In summary, it seems likely that the lower till of the dissected hummocky moraine was derived by flow from the lower series of debris bands, before the upper series was emplaced, and flowed into the sea or was inundated by the sea in its lower shell-rich part. The overlying bedded deposits probably represent different parts of an outwash system which again flowed into the sea in the east. The sands and gravels on the south-east side of the block $\mathrm{M}$, and the sands and the sands and silts on the south-western side of the channel O-P were probably subaerial, as neither they nor the underlying tills contain shells. The upper till is still in parts being deposited and it appears to be derived from the upper series of debris bands composed of unsorted material, which were not emplaced until after outwash deposition had ceased. Because of the difference in composition between the upper and lower series of debris bands, the upper and lower tills derived from them are also compositionally distinct. During the period of deposition of the upper flow till, outwash streams dissected the area.

Neither the gently folded configuration of the bedded deposits in the block M, nor the present surface topography, are necessarily related to the slopes down which the two flow tills 
moved. They merely reflect the differential ablation which has gone on at various times in response to the changing distribution of sediment thicknesses. The ease with which large masses of till are remobilized to flow down relatively low slopes ensures that both topographic expression and the pattern of differential ablation change rapidly.

The joints noted in the lower flow till of the hummocky moraine area also occur in flow tills on other glaciers. Features common to all such joints are their parallelism and even spacing, the angle of $45^{\circ}$ which they make with the surface over which they are flowing (the $45^{\circ}$ angle always faces up-slope), and their trend approximately normal to the direction of slope of this surface. They also seem to occur in slowly creeping tills of the type described in (i) on p. 398. In these the bottom surface of the till acts as a basal shear plane and thus the joints are second-order shears developed in response to sliding over this basal plane. They are particularly interesting in that they are much steeper than the Riedel shears which would be theoretically expected to develop at angles between $10^{\circ}$ and $30^{\circ}$. (Their presence indicates that little differential flow occurred within the till at the time of their formation.) Such Riedel shears often occur in silt- and clay-rich landslip material in temperate zones.

\section{Outwash deposits and moraine $G-H$ (Fig. 9)}

The continuation in the proglacial area of the zone of high shear separating the slowmoving Basissletta lobe of Valhallfonna, and the lobe which flows rapidly into the sea, is marked by a prominent ice-cored moraine (Fig. 9). This moraine is derived from debris contained in the basal part of the fast-moving ice lobe, which over-rides the sluggish Basissletta lobe to the north, thus bringing its basal debris to the surface. This is strikingly different from the finer-grained debris contained in the ice of the Basissletta lobe which it over-rides. It is a mixture of gravel and sand with some silt and clay. The gravel particles are well rounded. obviously a result of fluvial erosion, and the sand grains also have a surface form characteristic of fluvial grains, whereas some of the silt particles show the characteristics of glacially ground grains. Much of this material would thus appear to have been derived from fluvial sediments and, when released supraglacially as till, it is in some places indistinguishable from a fluvial deposit. A section at point F (Fig. Io) shows the contact between ice, which contains debris similar to that in the dissected hummocky moraine, and ice which has over-ridden it containing coarse gravelly debris.

The embayment between the moraine $\mathrm{G}-\mathrm{H}$ and the dissected hummocky moraine illustrates some of the varied processes of mass movement and fluvial deposition which may operate at glacier margins, and their potential to build up complex or simple layered sequences depending on the way in which these processes interact. Mass wasting of sediments which make up the dissected hummocky moraine is currently giving rise to a series of highly fluid flows of fine-grained sediments, which interfinger with the sands and gravels at the margin of the outwash system and flow into the hollows in which silt and clay have accumulated to the north-west of the moraine G-H (Figs. 9 and ro). Slow-moving masses of gravelly till from moraine G-H also flow into these basins of silt and clay accumulation. Much of this silt and clay is derived from the fine fraction of tills transported by small rivulets and sheet washes coming off the glacier front, and then re-deposited as fans and sheets of laminated silt and clay. In addition, the highly fluid flow tills of types (ii) and (iii) (p. 398-99) are transitional in their lower parts to mud-transporting sheet washes, which appear to result from the segregation of water from the parent mudflow, much of the laminated silt and clay coming from this source.

Much of this area is probably underlain by dead glacier ice, which contains relatively coarse gravelly debris in its upper part and fine-grained debris in the lower part. If, on amelioration of climate, the buried ice were to melt out, an extremely complex sequence might be expected to result (Fig. Iob): lower tills of at least two types, overlain in places by flow tills of varying composition, and in other places by thick stratified sequences and areas of complex hummocky moraine. Although Figure rob is hypothetical in that the melting out of the buried 
ice and further retreat of the glacier will produce considerable modification, it indicates the type of sequence of deposits which can be built up over a small area by the processes described above.

\section{StubendorfBreeN}

Stubendorfbreen is a long valley glacier in southern Ny Friesland flowing in a westerly direction between steep rock walls for much of its length and finally emerging onto a broad coastal flat, where it expands considerably in width (Fig. I). The northern margin of the glacier is fringed by an extensive ice-cored hummocky moraine, which is up to $1.5 \mathrm{~km}$ in width. To the north of this moraine lies a broad out wash plain which no longer takes the main part of the surface discharge of the glacier on its northern side, a task which is now performed by a broad, fast-flowing river running along the glacier surface inside the hummocky moraine arc. This river has deposited a complex series of fluvial gravels, sands and silts, which are up to $8 \mathrm{~m}$ thick, over a wide area of the glacier surface. The greatest part of this supraglacial sequence consists of planar laminated silts, which are probably a result of periodic flooding, and are identical in appearance to those in the terminal moraine of Dunerbreen. (Silts such as these form a very important part of the outwash of many Ny Friesland glaciers.) Cropping out on the up-glacier side of this fluvial complex is a series of debris bands of the type which occur on Duncrbreen and Valhallfonna, and which produce supraglacial flow tills ranging in composition from silt tills to poorly sorted bouldery tills. These tills run down the glacier surface into the zone of deposition of fluvial scdiments where complex interdigitations of till and bedded silts, sands and gravels occur. A wide variety of sedimentary structures, of the type which often puzzlc Plcistocene geologists in the field, occur as a result of the introduction of flow till into this active fluvial environment; once the possibilities of this interaction are realized, it is not difficult to visualize possible inodes of origin for many of the bed structures often seen in tills.

Examples of four types of structure are given below:

(i) On the inner part of the moraine a compact pebbly silt till $2 \mathrm{~m}$ thick, derived by flow from debris bands cropping out on the glacier surface, lies upon a series of fluvially deposited silts and fine sands, the interface being sharp and planar, and the silts beneath the till showing no sign of disturbance. If this till is traced laterally, thin layers of bedded silt appear within it, progressively increasing in thickness until the till is split into a series of thin ribbons which dic out laterally (Fig. 14). This interdigitation appears to be the result of outward flow of a serics of thin sheets of till into a zone of contemporaneous silt and sand accumulation at the edge of the broad flood plain of the supraglacial river.

(ii) The small cliff, in which the interstratified silt and till beds described in (i) occur, is unstable, often collapsing to give rise to a series of flows of mixed silt and till at its foot. These flows lie on a slope of $7^{\circ}$ and cover an area of approximately $50 \times 100 \mathrm{~m}$. When sectioned they show variations in composition from structureless tills similar to those in the small cliff from which they are derived, to tills with thin streaked-out wisps and laminae of silt and fine sand, tills containing clasts of laminated silt, and flows of stratified sandy silt with litte till content apart from small clots and balls. The flows may show parallel continuous laminae or wisps, or contorted and folded laminac. Similar flow tills with strcaking out of inclusions were noted on Valhallfonna (p. 405) and on Sorbreen (Boulton, 1967 ).

(iii) A possible mechanism for the production of large bedded inclusions within till was seen operating on the flood plain of the supraglacial river. A recent flood had given rise to a large pool, part of which was located on flow till. The submerged surface of 
this flow till was irregular and silt had been deposited in the hollows in the till. As till flows were active above the flanks of this pool, a further such flow could cover the till on the floor of the pool thus enclosing pods of bedded silt within the till.

(iv) Another interesting phenomenon is the occurrence of high-angle dykes of till which cut through the supraglacial silts and sands. Similar structures were noted on Sorbreen (Boulton, 1967 , fig. 4c). A likely explanation is that the ice beneath the silts is currently down-wasting, and that the bedded sediments are being slowly let down on both sides of high-angle englacial debris bands which are progressively released from the ice, thus producing intrusions of till into bedded sediment.

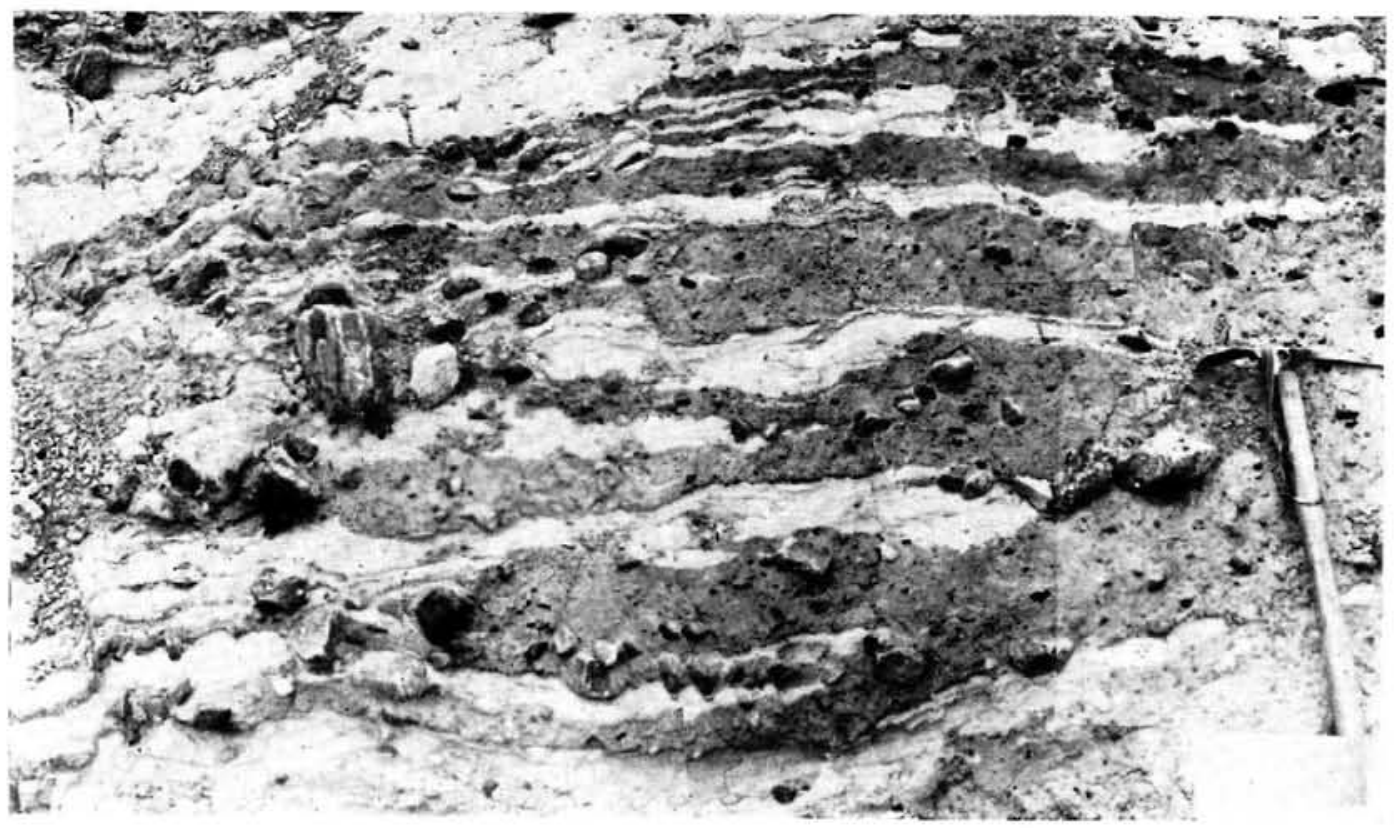

Fig. I4. A massive, 2 m-thick flow till at the right of the photograph, which passes towards the left into a sequence of laminated silts. It is presumed that this has resulted from the movement of a series of thin flow tills into a zone of fluvial and lacustrine silt accumulation.

\section{Discussion and Conclusions}

Supraglacial tills derived from thick bands of englacial debris are a common feature of many polar glaciers. They have been described by Lamplugh (I9I I), Gripp (1929), Donner and West (1957), Klimaszewski (1960) and Boulton (1967) from Vestspitsbergen and Nordaustlandet, and from the margin of the Greenland ice sheet by Koch and Wegener (1917), Bishop (1957) and several others. Fine-grained supraglacial tills, such as those commonly found in Spitsbergen and those described by Koch and Wegener are mobile and form flow tills which cover wide areas; Koch and Wegener described one such area as an unssierbaren Morast. The ease with which they flow allows accumulation in certain areas up to considerable thicknesses, Lamplugh ( $191 \mathrm{I}$ ) claiming 60 to $\mathrm{I} 00 \mathrm{ft}$ ( 18.3 to $30.5 \mathrm{~m}$ ) for such tills on Cora Island. Where local bedrock is not easily broken down, supraglacial tills derived from debris bands tend to be bouldery and do not form extensive flows. The tills in the Thule area described by Bishop (1957) and those at the margin of the Barnes Ice Cap on Baffin Island described by Goldthwait (195I) are of this type. 
Conditions for the development of flow tills

In some polar glaciers there are no thick debris bands cropping out on the glacier surface, and thus no extensive flow tills. These are generally glaciers which are flowing rapidly down a steep bed, or whose snouts are in a state of tension. In these cases there is no upward component of movement at the snout, the englacial bands remain at a low level near the glacier sole and flow tills rarely develop. The uprise of englacial debris to the glacier surface and subsequent development of flow tills are generally results of compression in the snout area of the glacier, induced by over-riding of bedrock obstacles, decrease in slope of the glacier bed or stagnation of ice at the frontal margin. The way in which the different velocity gradients produced by these interactions change the direction of glacier flow in the snout area have been discussed by Nielsen and Stockton (1956). The level at which debris is transported in the snout may also change during the history of a single glacier. At the end of the last century many Spitsbergen glaciers were advancing and had cliff-like fronts, termed "Chinese walls" (Garwood and Gregory, 1898 ). The ice foliation lay roughly parallel to the bed and debris bands in the basal part of the ice cropped out at a low level on these "Chinese walls". At the present day, however, the majority of these same glaciers are retreating and tend to have tapering snouts and steeply dipping debris bands in the terminal zone. (A good example of this is Dronbreen in Nordenskioldland which shows a "Chinese wall" termination in plates 17 and 18 of Garwood and Gregory's 1898 paper, but at the present day it has a tapering snout and high-angle debris bands giving rise to flow tills.)

The velocity gradient in the frontal area of an advancing glacier will tend not to show such a decrease towards the margin as in retreating or stationary glaciers, and it could even show a uniform velocity distribution or an acceleration towards the snout. Thus, advancing glaciers, especially those moving over a steep bed or one free of obstacles, are less likely to translate debris towards the surface along inclined planes in the terminal area than are stationary or retreating glaciers, and thus flow tills are more likely to develop in the latter.

\section{Mode of occurrence of flow tills}

Flow tills derived from subaerial outcrops of debris bands occur in two positions:

(i) Resting directly on glacier ice. In this case the ablation of the underlying ice is inhibited and may even cease. If the parent glacier is retreating, such areas of icecored moraine tend to stand out above the surrounding outwash system. If the climate were to ameliorate, it is likely that thick tills would form from the debris-rich ice core underlying the surface flow till.

(ii) Resting on supraglacial or extraglacial, fluvial or lacustrine deposits. In this case, complex till/stratified-sediment interbedding structures may occur, or the till may be massive and structureless, with a sharp planar base and with no disturbance of the underlying sediments. The lateral continuity of any one such till depends upon the distance which it is capable of flowing over other sediments; the maximum recorded extent of flow till over other sediments in the direction of flow was $0.5 \mathrm{~km}$ on Stubendorfbreen. Similar flow distances for clay-rich landslip debris on low slopes have been recorded by Skempton (1964), whilst there are numerous instances in which different types of mud flows have moved more than $\mathrm{r}$ km (e.g. Sharp and Nobles, r 953 ; Eden, r 967).

Supraglacial ablation tills, which build up in situ above the ice from which they are derived, cannot exceed in thickness the depth of annual thawing. Flow tills, however, may accumulate in hollows and flat areas in considerable thicknesses, a maximum of $5 \mathrm{~m}$ being recorded in this study.

"Controlled" and "uncontrolled" moraine forms

Hummocky ice-cored moraines lie beyond the active snouts of many Vestspitsbergen and Nordaustlandet glaciers, much of the surface till which coats these moraines being derived by 
flow from englacial debris bands. These moraines may consist of a large number of mutually parallel ridges which are themselves parallel to the glacier front (the outer part of the moraine of Dunerbreen; Fig. 2), or of a series of hummocks and mounds arranged in no discernible pattern (e.g. the moraine ridges between $\mathrm{A}$ and $\mathrm{B}$ on Dunerbreen; Fig. 2). Pleistocene features, which are not ice-cored but similar to these in form, have been aptly described by Gravenor and Kupsch (1959) as "controlled" and "uncontrolled" forms, respectively.

An explanation of the origin of "controlled" and "uncontrolled" ice-cored moraines in Spitsbergen is provided by the observations on Dunerbreen. Between D and F in Figure 2, moraine ridges are strongly "controlled", lying parallel to the glacier front with maximum thicknesses of till lying in the furrows between ridges. This till is derived from a series of thick englacial debris bands which strike parallel to the glacier front. The formation of the controlled forms can be envisaged if it is assumed that a series of such widely spaced debris bands initially deposited till on the glacier surface, so that the greatest thicknesses lay along narrow belts parallel to the strike of the parent debris bands. The rate of ablation of the underlying ice would thus be changed, with the least ablation beneath the thick till belts, thus producing a series of ridges and furrows in the underlying ice which would control the locus of further flow-till accumulation and perpetuate a "controlled" ridge-and-furrow topography, even though the relative heights of different features might change considerably. Between A and B (Fig. 2) there is an area of "uncontrolled" hummocky moraine, the surface till of which is derived from debris uniformly distributed in the underlying ice. Thus, when this debris is released at the glacier surface, it forms a thin, irregular till cover, in which the greatest thicknesses are not distributed along definite lines but occur at random. The consequent differential ablation of the underlying ice thus produces an irregular, "uncontrolled" hummocky topography which will determine the locus of accumulation of further flow tills and, although relative heights of features might change, an "uncontrolled" topography would probably be perpetuated. (The gradual change in the relief of an irregular thickness of sediment overlying an ablating ice surface has been described by Corte (1959).) Thus the development of these "controlled" and "uncontrolled" features is essentially similar, and on many glaciers there is a transition between them.

Supraglacial moraines derived from englacial debris bands in the Thule area of Greenland have been described by Bishop (1957) as "shear moraines" on the assumption that the debris is incorporated in the glacier by thrusting or shearing. However, there is no evidence to show that the debris bands described in this paper are incorporated by shearing or even that they are shear planes themselves. The term "shear moraine" is thus not appropriate to the supraglacial till derived from debris bands in the glaciers described.

Sections such as those described in deposits at the margins of Vestspitsbergen glaciers are relatively rare. The observations presented here were mainly made on remnants of deposits which have been largely destroyed by erosion. They do however indicate the type of sequence which builds up by the operation of the processes described here. These processes are very widespread at glacier margins in Vestspitsbergen and thus it seems reasonable to assume that large areas beyond these glacier margins, which have not been dissected by erosion, might conceal sequences of the types described in the erosional remnants. Indeed, many of the tills, especially those at or near surface, which occupy broad areas beyond glacier margins may well be flow tills.

Many supraglacial flow tills described from Vestspitsbergen are similar to tills which commonly occur in areas of Pleistocene glaciation and which are generally thought of as subglacial in origin. The overconsolidated state of some of these latter tills is generally attributed to compaction under a considerable ice load, whereas this could be due to subacrial dryingout. Thus it is conceivable not only that some of these Pleistocene tills are supraglacial in origin, but that certain multi-till sequences, interpreted in terms of glacier advance, retreat 
and re-advance, are merely the product of a single retreating ice sheet producing supraglacial flow tills at its margin.

\section{Acknowledgements}

Most of these observations were made during the 966 Cambridge Expedition to Vestspitsbergen (Harland and Wallis, 1966 ), and the author wishes to thank the director, W. B. Harland, and lcader, R. H. Wallis, for their co-operation. Assistance in the field was given by D. Smith and M. R. Rhodes, and aid and constructive criticism during preparation by Professor F. W. Shotton and Dr F. Moseley.

MS. received I February 1968

\section{REFERENGES}

13ishop, B. C. 1957. Shear moraines in the Thule area, northwest Greenland. U.S. Snow, Ice and Purnafrost Research Ertablishment. Research Report 17.

Blake, W., $j$. 1961. Radiocarbon dating of raiscd beaches in Nordaustlandet, Spitsbergen. (In Raasch. G. O., ed. Geology of the Arctic: procedings of the first international symposium on Arctic geologe held in Calgary. Alberla. January $I I-13,1960$. 'I'oronto, University of I Toronto Press, Vol. I, p. I33-45-)

Boulton, G. S. Igfin. The development of a complex supraglacial moraine at the margin of Sorbreen, $\mathrm{Yy}$ Friesland, Vestspitsbergen. 7ournal of Giaciolog. Vol, 6, No. 47, p. 717-35.

Corte, A. E. rg59. Experimental formation of sorted patterns in gravel overlying a natting ice surface. $U . S$. Snote. Ice and Pormafrost Research Establishment. Research Report 55.

Corte, A. E., and Higashi, A. 1964. Experimental research on desiccation cracks in soil. Li.S. Cold Regians Research and Engineering Laburalory. Research Report 66.

Donner, J. J., and West, R. G. 1957. The Quaternary geology of Brageneset, Nordaustandet, Spitsbergen. Norsk Polarinstituit. Skrifter. Nr. Iog.

Eden, N. J. 1967. Buricd soil profile under apron of an earthflow. Geological Socieb of America. Buletin. Vol. 78. No. 9. p. I $83-84_{3}$

Garwood, 1. J., and Gregory, J. W. I 898 . Contributions to the glacial geology of Spitsbergen. Quarlerly Journal of the Geological Society of London. Vol. 54. No. 214. p. $197-227$.

Goldithwait, R. P. 195i. Dovelopment of end moraines in east-central Baffin Island. Foumal of Geolog, Vol. 59. งo. 6, P. $56 \mathrm{j} 7-77$.

Gravenor, C. P., and Kupsch. W. O. 1959. Icc-disintegration features in western Canada. Fournal of Geolog', Vol. 67, No. 1, p. $48-64$

Gripp, K, 1929. Glaciologisehe und geologische Ergebnisse der Hamburgischen Spitzbergen-Expedition 1927. Nalurvissenschaflicher Verein in Hamburg. Abhondhungen aut dem Gebiet der Naturwissenschaften, Bd. 22, $\mathrm{Ht}, 2-4$, p. 146.249 .

Harland. W. B., and Wallis, R. H. 1966. Cambridge Spitsbergen Expedition, iy65. Polar Record, Vol. 13, No. 83, p. $192-94$.

Klimaszewski, M. 1960. Studia geonorfologiczne w zachodnicj cześci Sipitsbergenu miedzy Kongs-Fjorden a Eidem-Bukta. Zeszpty Naukowe Uniwersylelu Jagialloriskiego. Prace Grograficzne. Seria Nowa (Kraków). Zeszyt I.

Koch, J. P., and Wagener, A. I917. Die glaciologischen Beobachtungen der Danmark-Expedition. Meddelelser on Gronland, Bd. $46, \mathrm{Nr}$. [.

Lamplugh, G. W. rgi . On the shelly moraine of the Sefström glacier and other Spitsbergen phenomena illustrative of British glacial condlitions. Proceedings of the Yorkshire Geological Soctely. Vol. 17 . No. 3. P. 2 I6-4I.

Nielsen, L. E, and Stockton, F. D. 1956. Flow patterns in glacier icc. Journal of Lipplied Plysics, Vol. 27, No. 5. P. $44^{8-53}$.

Sharp, R. P., and Nobles, L. H. I953. Mudflow of r94I at Wrightwood, southern Califonta. Bulletin of the Geological Society of Anerica. Vol, 64, No. 5, p. 547-60.

Sharpe, C. F. S. I g'8 8. Landslides and relaled phetomena. New York. Columbia University Press. (Columbia Geomorphic Studies, No. 2.)

Skempton, A. W. 1964. Iong-term stability of clay slopes. Géotechnique, Vol. 14, No. 2, p. $77-101$. 